$$
\forall
$$




\section{NOVAS FORMAS PARA FINANCIAR VELHOS PROBLEMAS}

A

$G V$-executivo publica nesta última edição do ano um caderno especial sobre finanças sociais. Recente mapeamento sobre negócios de impacto social da Pipe ${ }^{1}$ mostrou que existem 597 empreendimentos no Brasil que seguem a Carta de Princípios para Negócios de Impacto no Brasil, que tem por base:

- compromisso com a missão social e ambiental;

- compromisso com o impacto social e ambiental monitorado;

- compromisso com a lógica econômica;

- compromisso com a governança efetiva.

Conhecimento em microfinanças, ampliação do microcrédito e novas tecnologias financeiras estão sendo utilizados para esse fim. No século XXI, os negócios buscam cada vez mais conciliar o lucro necessário para a sobrevivência da empresa com objetivos e ações que possam diminuir desigualdades e promover a inclusão financeira.

Nessa direção, o artigo Os ganhos dos investimentos de impacto, de Diogo Quitério, Celia Cruz e Beto Scretas, mostra como os investimentos têm se direcionado para negócios que promovem melhoria mensurável de problemas sociais e ambientais, especialmente por seu potencial de escala. Ariádne Scalfoni Rigo trata dos bancos comunitários, que criaram uma metodologia para oferecer serviços financeiros à população mais pobre. Julio Leandro e Lauro Gonzalez demonstram a importância da educação financeira, que precisa ser conciliada com valores e ética. E os benefícios e desafios do famoso blockchain são debatidos por Frederic de Mariz em Tecnologia Inclusiva?

Os demais artigos que compõem esta edição abordam temas relevantes para o momento atual: Cláudio Gonçalves Couto fala da gestão pública no novo governo; José Renato Salles aponta que o coaching não é a panaceia que resolve todos os problemas das empresas e dos executivos; e Daniele Eckert Matzembacher, Marcia Dutra de Barcellos e Luciana Marques Vieira argumentam como o setor público, empresas e organizações não governamentais (ONGs) podem obter ganhos econômicos, sociais e ambientais ao tratar dos desperdícios que ocorrem na produção de alimentos. O número conta também com as colunas: Fora da Caixa, de Samy Dana; Sociedade e Gestão, de Marco Antonio Carvalho Teixeira; Economia, de Paulo Sandroni; e Recursos Humanos, de Maria José Cury.

Abrindo a edição, destaca-se a entrevista de Adriana Wilner com Ariel Lambrecht, sobre as estratégias da Yellow Bike.

Desejamos aos nossos leitores um fim de ano com boas festas. Que 2019 seja guiado por princípios iluministas e que possamos alcançar, cada vez mais, o bem-estar físico e mental e uma sociedade mais justa.

Aguardem as próximas edições da GV-executivo em 2019, com muitos temas importantes para o desenvolvimento das pessoas e das empresas.

Maria José Tonelli - Editora chefe

Adriana Wilner - Editora adjunta

*Referência: pipe.social/mapa2017 